\title{
REAKTUALISASI TEKNOLOGI FOTOGRAFI ABAD KE-19 DAN 20 Studi Kasus pada Kelompok Kegiatan Mahasiswa KOPPI ISI Yogyakarta
}

\author{
Irwandi \\ Dosen Jurusan Fotografi, Fakultas Seni Media Rekam, ISI Yogyakarta \\ Jalan Parangtritis Km 6,5 Bantul, Yogyakarta \\ No.Hp.+081328656252,E-mail: insinyurwandi@yahoo.com
}

\begin{abstract}
Abstrak
Kecanggihan teknologi fotografi digital saat tidak memuaskan beberapa fotografer, terutama yang condong ke fotografi seni. Sebagai gantinya, mereka melihat kembali teknik fotografi lama, seperti yang dilakukan pada abad ke-19, antara lain cyanotype, salt print, vandyke, dan cetak gum bichromate. Sebagian besar teknik cetak diaktualisasikan ulang oleh sejumlah fotografer dengan orientasi yang berbeda. Artikel ini membahas bagaimana Kelompok Kegiatan Mahasiswa, Keluarga Old Photographic Processes ISI Yogyakarta (KOPPI) melakukan lebih dari sekadar rekonstruksi teknis. Mereka menggunakan media unik ini untuk menyampaikan pesan tentang masalah pribadi dan budaya. Teknik pengamatan partisipatif digunakan selama empat proses penciptaan: pengenalan, eksplorasi, eksperimen, dan presentasi. Ditemukan bahwa dalam menggunakan teknik pencetakan foto lama para peserta harus menegosiasikan tiga aspek, yaitu pemahaman teknis, material, dan konsep budaya. Setelah mereka mencapai pemahaman teknis dan material yang memadai, para peserta mulai mengeksplorasi isu-isu budaya. Isu budaya tentang penyimpangan perilaku, kesedihan, dan respons masyarakat terhadap kehidupan sehari-hari telah diangkat menjadi tema pekerjaan melalui teknik pencetakan foto lama. Anggota KOPPI memanfaatkan kesan kuno dan fleksibilitas media cetak untuk mewujudkan hal tersebut.
\end{abstract}

Kata kunci: reaktualisasi, cetak fotografi abad ke-19 dan 20, fotografi cetak tua

\begin{abstract}
Re-actualization of the $19^{\text {th }}$ and $20^{\text {th }}$ Century Photographic Printing Technology: The Case of KOPPI Student Activity Group. The sophistication of digital photography technology does not satisfy some photographers, especially those who tend towards art photography. Instead, they looked back at old techniques, such as those of the 19th-century based on chemical principles, including cyanotype, salt print, vandyke print, and gum bichromate print. Most of the printing techniques are re-actualized by a number of photographers with different orientations. This paper examines how Old Photographic Processes Student Activity Group of ISI Yogyakarta (KOPPI) did more than just technical reconstruction, They used these unique media for conveying messages of personal and cultural issue. Participatory observation techniques were used during the four processes of creation: introduction, exploration, experimentation, and presentation. The finding showed that in using the old photo printing technique the participants had to negotiate three aspects, namely the technical understanding, materials, and cultural concepts. After they reached a sufficient technical and material understanding, the participants began to explore cultural issues. Cultural issues about deviations of society's behavior, sadness, and society's response to every day life have been raised to be the themes of the work through the old photo printing technique. Members of KOPPI take advantage of the old-fashioned impressions and flexibility of print media to realize these things.
\end{abstract}

Keywords: re-actualization, 19 th and $20^{\text {th }}$ century photographic printing, old print photography 


\section{PENDAHULUAN}

Sudah tidak terhindarkan, bahwa arus besar fotografi masa kini ialah fotografi yang berbasis pada teknologi digital. Berintegrasinya teknologi digital dan fotografi memberikan banyak kemudahan bagi pemakai fotografi, termasuk seniman untuk mengolah bahasa-bahasa visual guna menyampaikan ide-gagasan dalam berkarya. Buktinya, kini banyak hadir karya-karya seni fotografi yang wujud dan tampilannya secara mudah dan cepat hanya mungkin dihadirkan dengan pemanfaatan teknologi digital. Misalnya melalui aplikasi editing yang terdapat di smart phone, dalam hitungan detik, user sudah bisa mendapatkan file foto dengan efek visual yang beragam dan membagikannya kepada khalayak luas melalui media social. Contoh lainnya ialah pemilihan media cetak fotografi yang semakin beragam dengan ukuran, jenis permukaan yang dapat disesuaikan dengan keinginan pengkarya, ditambah dengan akurasi warna yang sangat baik.

Berlawanan dengan itu, teknologi fotografi analog, walaupun belum hilang sama sekali dan mulai tumbuh kembali, penggunaan fotografi analog kini sudah sangat terbatas. Praktik fotografi analog kebanyakan hanya dilakukan oleh komunitas-komunitas fotografi lokal di kota-kota tertentu. Di sisi lain, praktik fotografi analog abad ke-19 dan 20 masih wajib dipelajari di Program Studi Fotografi, Fakultas Seni Media Rekam, ISI Yogyakarta selama dua semester. Mata kuliah tersebut bagi sebagian mahasiswa dipandang cukup berat, namun bagi sebagian yang lain merupakan mata kuliah yang menarik. Terasa berat karena memang untuk mendapatkan alat dan material fotografi analog kini tidak mudah. Bila pun ada, harganya cukup mahal. Masih ditambah dengan proses pengkaryaan yang memakan waktu dan membutuhkan ketelitian sehingga mata kuliah ini dianggap memerlukan energi yang banyak. Namun bagi sebagian mahasiswa yang lain, mata kuliah ini dipandang sebagai sarana untuk meningkatkan kekuatan karakter dalam berkarya dan bereksperimentasi. Mahasiswa yang masih ingin mengembangkan minat mereka terhadap praktik fotografi abad ke-19 dan 20 dapat mengambil pilihan untuk bergabung di kelompok kegiatan mahasiswa Keluarga Old Photographic Processes ISI Yogyakarta (KOPPI). KOPPI hingga saat ini masih aktif melakukan berbagai aktivitas, diantaranya melakukan pameran, workshop, dan melakukan berbagai eksperimen pada praktik cetak foto hitam putih dan old photographic processes. Eksperimentasi yang dilakukan berkaitan dengan proses pencetakan, alat dan bahan, serta tema-tema yang ditampilkan melalui karya.

Artikel ini akan membahas bagaimana para anggota KOPPI memanfaatkan kekhasan media fotografi hitam putih dan old photographic process dalam berkarya. Hal yang akan menjadi fokus pembahasan ialah bentukbentuk negosiasi teknik, media, dan tema karya yang mengetengahkan isu-isu personal dan budaya. Namun, pembahasan akan diawali dengan gambaran singkat tentang KOPPI, proses praktik fotografi hitam putih (abad ke20) dan old photographic processes (abad ke19). Lebih tegasnya, ada tiga hal penelitian yang akan dibahas dalam makalah ini, yaitu (1) apa itu KOPPI; (2) bagaimana gambaran praktik fotografi hitam putih dan praktik old photographic processes yang dilakukan oleh KOPPI; dan (3) bagaimana negosiasi yang dilakukan anggota KOPPI dalam perihal teknis, material, dan karakter karya foto hitam putih dan old photographic process sebagai upaya mengetengahkan isu-isu budaya di Indonesia. 
Metode yang digunakan dalam penulisan makalah ini ialah studi pustaka, studi dokumen, dan pengamatan. Studi pustaka dilakukan pada sumber-sumber referensi tentang praktik fotografi hitam putih dan old photographic processes. Sumber-sumber pustaka yang dimaksud antara lain ialah buku (1) A Guide To Early Photographic Process, terbitan Victoria \& Albert Museum with Hurtwood Press, London (Coe \& Haworth, 1983); Historic Photographic Processes, terbitan ALLWORTH PRESS, New York (Farber, 1998) ; dan Creative Black and White Photography: Advance Camera and Darkroom Techniques, Allworth Press, New York (Suess, 2003). Keempat buku tersebutmembahas secara detail berbagai tahap perwujudan foto hitam putih analog dan old photographic processes, yang meliputi persiapan, alat, bahan, teknis, dan eksperimentasi yang dapat dilakukan.

Studi dokumen yang dilakukan meliputi telaah pada dokumen-dokumen visual dan audiovisual yang dihasilkan oleh KOPPI dalam kurun waktu empat tahun. Dokumendokumen itu meliputi rekaman-rekaman proses penciptaan, dokumentasi pameran, dan arsiparsip katalog yang telah diterbitkan. Adapun pengamatanjuga dilakukan pada anggota KOPPI dalam berbagai aktivitas yang dilakukan. Hasil penelahaan pada berbagai sumber dan data penelitian kemudian akan dibahas, dianalisis, dan disajikan secara deskriptif.

\section{PEMBAHASAN}

Keluarga Old Photographic Processes ISI Yogyakarta (KOPPI) dan Perannya di Masyarakat

KOPPI adalah salah satu Kelompok Kegitan Mahasiswa Program Studi Fotografi, Fakultas Seni Media Rekam, ISI Yogyakarta.
Kelompok ini diresmikan pada tahun 2014, walaupun sesungguhnya sudah mulai beraktivitas sejak 2012. Awalnya, KOPPI hanya berorientasi pada anggotanya yang berstatus sebagai mahasiswa di Fakultas Seni Media Rekam, ISI Yogyakarta. Artinya para anggota KOPPI memanfaatkan kelompok ini untuk memperdalam kemampuan mereka dalam menciptakan karya fotografi analog dan fotografi cetak tua, yang hasil-hasilnya mereka pamerkan di berbagai acara di Yogyakarta dan beberapa kota lain di Indonesia. Namun tidak lama setelah itu, hasil-hasil karya yang dipamerkan mendapat sambutan baik di masyarakat sehingga KOPPI mulai mendapat tawaran dari berbagai pihak untuk menjadi narasumber workshop fotografi alternatif. Workshop-workshop itu biasanya dilakukan bersamaan dengan pameran yang diadakan KOPPI. Beberapa kota yang pernah menjadi tempat pameran KOPPI antara lain Jakarta (Galeri Foto Jurnalistik ANTARA); Yayasan Pusat Kebudayaan Bandung dalam acara Bandung Photography Month; Malang Photofest; dan Solo Photofestival. Dampak lain dari aktivitas-aktivitas tersebut, nama KOPPI mulai sering masuk dalam pemberitaan media cetak dan elektronik, baik media lokal maupun nasional. Cepatnya KOPPI dikenal oleh masyarakat tidak terlepas dari keunikan media fotografi yang digunakan, yaitu fotografi hitam putih dan foto cetak tua. Kedua praktik ini sudah ditinggalkan oleh arus besar fotografi sejak kemunculan fotografi digital. Praktik fotografi yang didalami oleh KOPPI mengundang rasa penasaran khalayak untuk mencoba sensasi fotografi masa lalu. Workshop bersama KOPPI menjadi ajang peserta dapat merasakan kembali bagaimana memproses film seluloid, bahkan membuat kertas foto yang peka cahaya. 


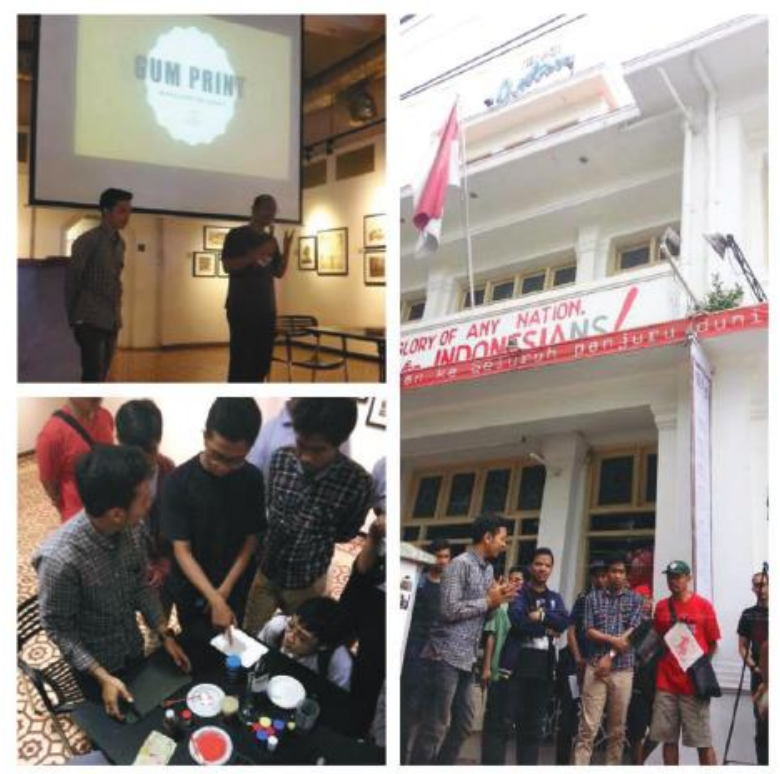

Gambar 1. KOPPI dalam sebuah acara fotografi di Jakarta

(Sumber: dokumentasi pribadi)

\section{Old Photographic Processes}

Saat ini, metode cetak yang dilakukan pada masa awal ditemukannya fotografi sering disebut dengan istilah old print atau old photography process. Ada juga yang menyebutnya dengan early photography process atau hand made photography. Berdasarkan nama dan istilah-istilah tersebut tergambarkan bahwa proses ini harus dilakukan dengan tangan, tanpa proses masinal. Di sinilah letak daya tariknya, pelaku cetak dapat merasakan langsung sebagian dari sensasi fotografi masa lalu, tepatnya pada pertengahan abad ke-19.

Dalam wacana fotografi seni di Indonesia, penciptaan dengan memanfaatkan metode fotografi tua (old print) juga jarang dilakukan karena minimnya informasi tentang hal tersebut. Padahal old print sebagai proses cetak fotografi pada masa lalu menyimpan banyak daya tarik dan manfaat yang dapat dipetik. Dari sisi kependidikannya, reaktualisasi proses fotografi tua dapat dijadikan sarana untuk memberi pemahaman akan prinsip perekaman imaji menuju media peka cahaya, memahami prinsip imaji positif-negatif sebagai dasar pengetahuan tentang reproduksi imaji, -dalam hal ini proses reproduksi fotografiserta manfaat pengetahuan lainnya. Adapun dari sisi artistiknya, perwujudan karya dengan memanfaatkan metode old print menyimpan banyak daya tarik yang menjadikan metode ini layak untuk dipelajari, antara lain ialah tampilan visual bernuansa "tempo doeloe" yang berbeda dari kebiasaan fotografi masa kini. Membuat dan mencetak kertas foto dengan metode old print juga membuka ruang ekpresi maupun eksperimen yang luas bagi para pelakunya. Berbagai keuntungan teknis old print dapat digunakan kreator fotografi untuk menyampaikan gagasannya dengan cara yang unik sekaligus melakukan berbagai eksperimen yang berkaitan dengan media cetak yang digunakan, konsentrasi bahan kimia, dan mencoba berbagai kemungkinan lainnya. Tidak adanya insan fotografi seni di Indonesia yang memanfaatkan metode old print bisa jadi disebabkan minimnya informasi yang diketahui oleh masyarakat tentang metode cetak tersebut dan adanya anggapan bahwa untuk membuat selembar kertas foto dibutuhkan teknologi yang serba rumit, ditambah lagi dengan mahalnya alat dan bahan kimia yang harus dibeli.

Terdapat banyak jenis/metode cetak foto abad ke-19, diantaranya (1) salt print, (2) albumen print, (3) printing out paper, (4) vandyke brown print, (5) cyanotype, dan (6) gum bichromate print. Namun, berdasarkan pertimbangan ketersediaan bahan maka sejauh ini KOPPI lebih berkonsentrasi pada jenis cetakan vandyke brown print, cyanotype, gum bichromate, dan cetak foto hitam putih. 


\section{Gambaran Ringkas Proses Fotografi Cetak Tua}

Secara ringkas, untuk menghasilkan cetakan dengan cara lama perlu beberapa tahapan. Tahapan untuk seluruh jenis cetakan dapat dikatakan hampir sama. Biasanya, perbedaan masing-masing jenis cetak terletak pada material/ bahan kimia yang digunakan dan sedikit perbedaan dalam proses pembilasan foto. Berikut ini gambaran proses cetak foto abad ke-19.

\section{Membuat Film Negatif/Positif}

Pada abad ke-19, film negatif yang digunakan dalam proses pembuatan old print ialah negatif yang dicetak di atas kaca atau kertas, namun pada saat ini film negatif kaca dapat digantikan dengan film ortho atau plastik transparan yang dirancang untuk desktop printer. Pembuatan film dilakukan melalui proses digitalisasi foto asli (yang akan dicetak), untuk kemudian dicetak ke atas film ortho dalam bentuk negatif. Mengingat proses old print yang mengharuskan penyinaran dilakukan dengan keadaan film yang menempel pada kertas (contact print), maka ukuran film yang dibuat harus sama dengan ukuran foto yang diinginkan.

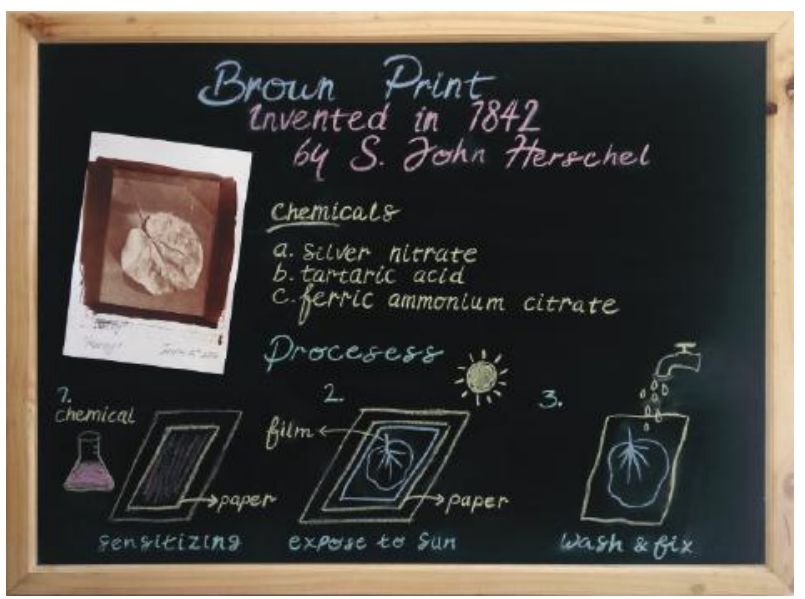

Gambar 2. Skema proses fotografi cetak tua (Sumber: Katalog Pameran The Power of Art, Dies Natalis 25 Tahun Program Studi Pengkajian Seni Pertunjukan dan Seni Rupa, Sekolah Pascasarjana UGM Yogyakarta, 17-29 Oktober 2016)

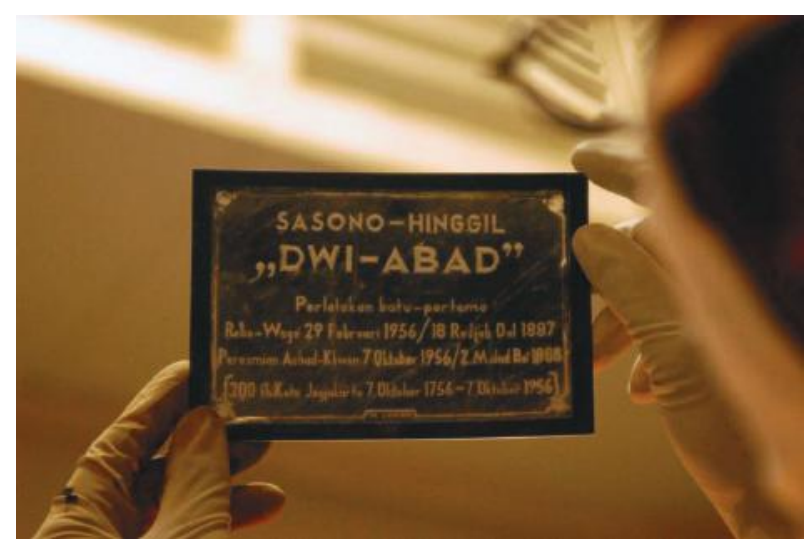

Gambar 3. Film positif/negatif

(Sumber: dokumentasi pribadi)

\section{Membuat Cairan Peka Cahaya}

Cairan peka cahaya perlu disiapkan. Bahan dan cara pembuatan cairan tergantung pada jenis cetakan yang akan dibuat. Bahanbahan kimia yang biasa digunakan antara lain silver nitrat, potassium ferricyanide, dan bahan-bahan lain yang dicampur dengan air suling. Acuan kuantitas bahan yang diperlukan didapat dari referensi-referensi yang didapat melalui studi pustaka.
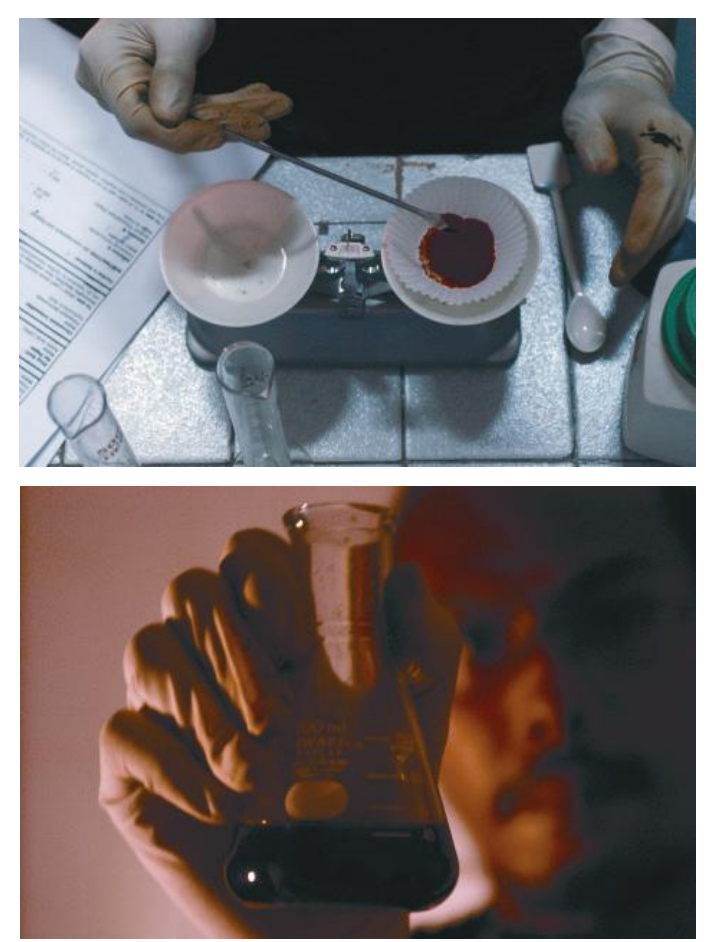

Gambar 4. Cairan peka cahaya (Sumber: dokumentasi pribadi) 


\section{Sensitizing}

Langkah ini bertujuan untuk menjadikan kertas atau media yang akan dicetak peka terhadap cahaya matahari, atau cahaya yang mengandung radiasi ultra violet. Kertas atau media yang akan dipekakan diolesi dengan cairan peka cahaya dan dikeringkan di tempat yang redup. Pengolesan dapat dilakukan dengan bantuan kuas, spon, kapas, dan lain sebagainya. Dalam tahap ini biasanya terjadi eksperimentasi pemilihan media yang akan dicetak, meliputi jenis, tekstur, dan warna kertas; kain, kayu, kaca, dan keramik.

\section{Penyinaran}

Media yang telah dipekakan kemudian dipasang di bingkai khusus bersama dengan film yang telah disiapkan untuk kemudian disinari di bawah sinar matahari langsung. Durasi penyinaran sangat tergantung pada kekuatan cahaya matahari pada saat mencetak. Lazimnya penyinaran dilakukan selama 5-10 menit (Bas, 1971).

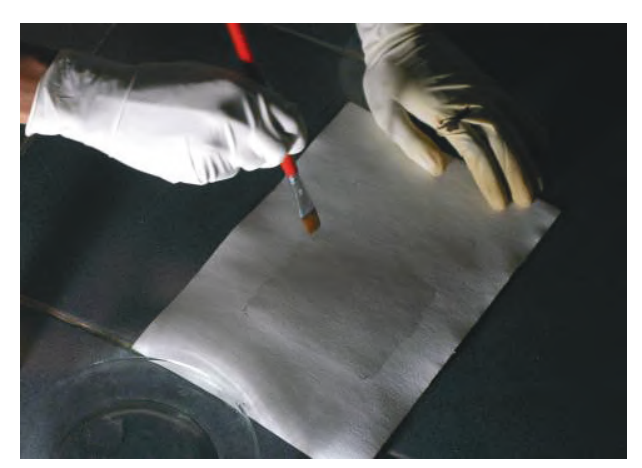

Gambar 5. Proses pengolesan (Sumber: dokumentasi pribadi)

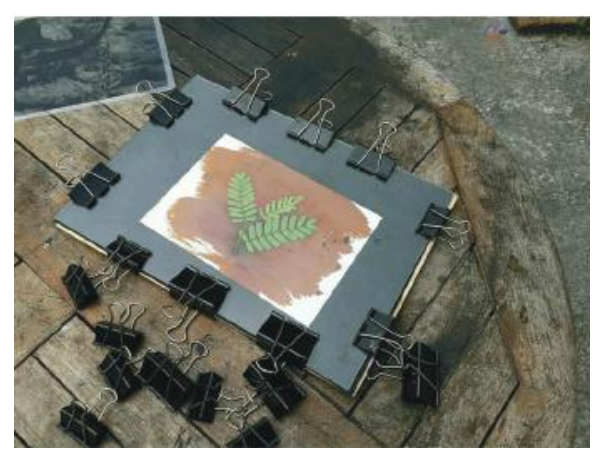

Gambar 6. Proses penyinaran (Sumber: dokumentasi pribadi)

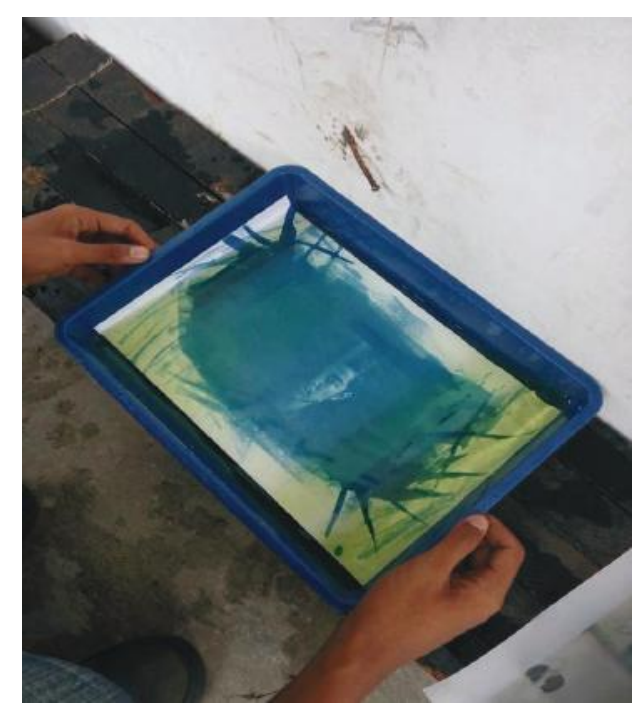

Gambar 7. Proses pembilasan (Sumber: dokumentasi pribadi)

\section{Pembilasan}

Pembilasan dilakukan untuk membersihkan sisa-sisa bahan kimia yang tidak bereaksi dengan cahaya. Di tahap inilah gambar yang terbentuk dari penyinaran dibersihkan dan diawetkan. Cetakan yang telah disinari dibilas dengan air dan sodium thyosulfate.

\section{Fotografi Hitam Putih}

Teknologi fotografi pada abad ke-19 masih berbasis pada fotografi pelat basah, yaitu media peka cahaya yang menjadi film dan hanya dapat bekerja dengan baik dalam keadaan basah. Ini artinya, fotografer harus menyiapkan film dan berbagai perangkat pemotretan sesaat sebelum pemotretan dilakukan. Tentu saja ini sangat merepotkan. Hal ini menjadi tantangan bagi George Eastman (pendiri perusahaan Kodak) untuk menciptakan film yang lebih ringkas. Melalui berbagai eksperimen, pada tahun 1900 Kodak memasarkan fotografi "kering" yang lebih ringan dan compact. Temuan Kodak ialah fotografi berbasis pita selulosa gulungan yang kecil dan ringan. Tidak hanya itu, Kodak juga membangun sebuah sistem di mana hasil pemotretan/ film yang telah dipakai dapat diproses di kios-kios penyedia jasa pemrosesan 
film dan jasa pencetakan foto (Brooke-Ball, 1997). Sistem inilah yang lazim disebut fotografi analog dan bertahan selama satu abad hingga penemuan teknologi fotografi digital.

Untuk melakukan praktik fotografi analog, dibutuhkan sebuah sebuah sistem tata kerja dan peralatan, misalnya kamera, film, bahan-bahan kimia, kamar gelap, dan kertas foto (Suess, 2003). Praktik fotografi analog hingga saat ini masih dilakukan oleh sejumlah peminat fotografi. Penggunaan media ini lebih berorientasi pada penciptaan karya seni dan keinginan bereksperimentasi guna mendapatkan kepuasan berkarya.

Secara ringkas, proses praktik fotografi analog dimulai dengan proses pemotretan, pencucian film, pencetakan, dan penyajian. Pada fotografi hitam putih analog, seluruh proses dapat dilakukan sendiri dengan menggunakan alat-alat khusus yang biasanya terdapat pada sekolah-sekolah fotografi.

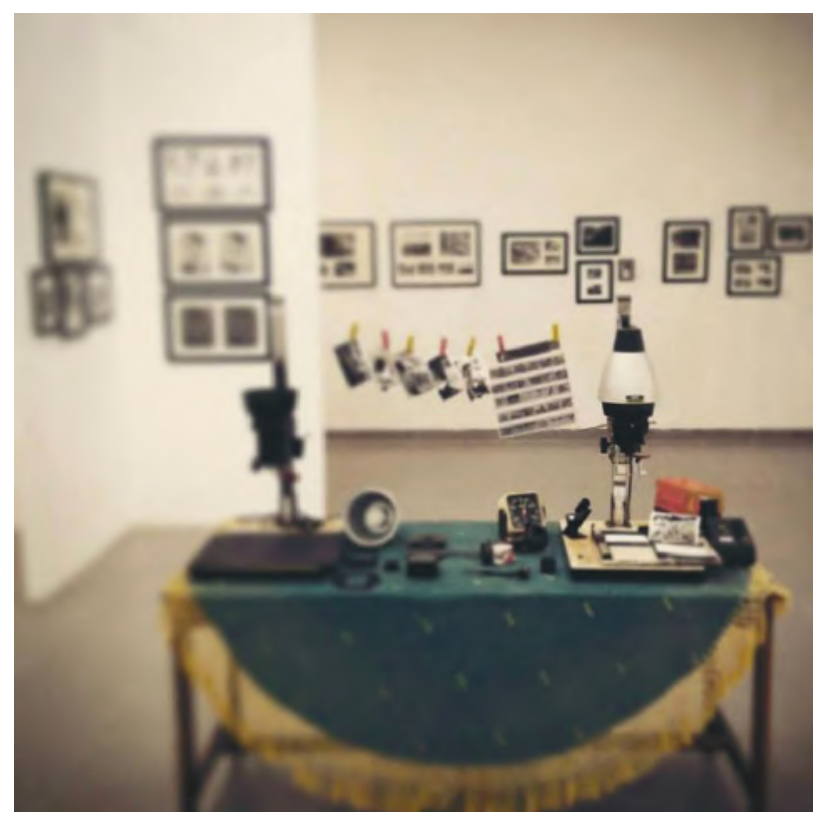

Gambar 8. Ilustrasi foto hitam putih (Sumber: dokumentasi pribadi)

\section{Konsep dan Proses Pengkaryaan KOPPI}

Telah disebutkan di awal bahwa KOPPI bersama para anggotanya aktif berkarya dan melaksanakan kegiatan kemasyarakatan melalui praktik fotografi cetak tua dan fotografi analog. Berikut ini akan dibahas seberapa karya KOPPI yang secara khusus mengetengahkan isu-isu personal dan budaya. Alasan pemilihan fokus ini ialah adanya kemauan dari para anggota KOPPI untuk tidak sekadar piawai dalam hal teknis cetak foto analog dan foto abad ke-19. Para anggota menginginkan lebih, mereka ingin bagaimana praktik yang unik ini dapat dimanfaatkan untuk menampilkan karya yang bersifat eksperimentatif sekaligus konseptual, serta dapat membicarakan tema-tema tertentu yang hanya bisa dicapai melaui praktik ini. Keinginan itu memang cukup beralasan mengingat saat ini berkat kemajuan teknologi manipulasi gambar, berbagai efek dapat dihasilkan melalui proses digital. Hingga saat ini beragam eksperimentasi masih dilakukan untuk menemukan bentuk-bentuk karya yang khas sehingga dapat dijadikan alasan mengapa para anggota KOPPI tetap bertahan pada praktik cetak foto analog dan cetak tua. Berikut ini akan diulas beberapa karya anggota KOPPI yang dipandang dapat menggambarkan pencapaian mereka dalam hal eksplorasi dan tema. 


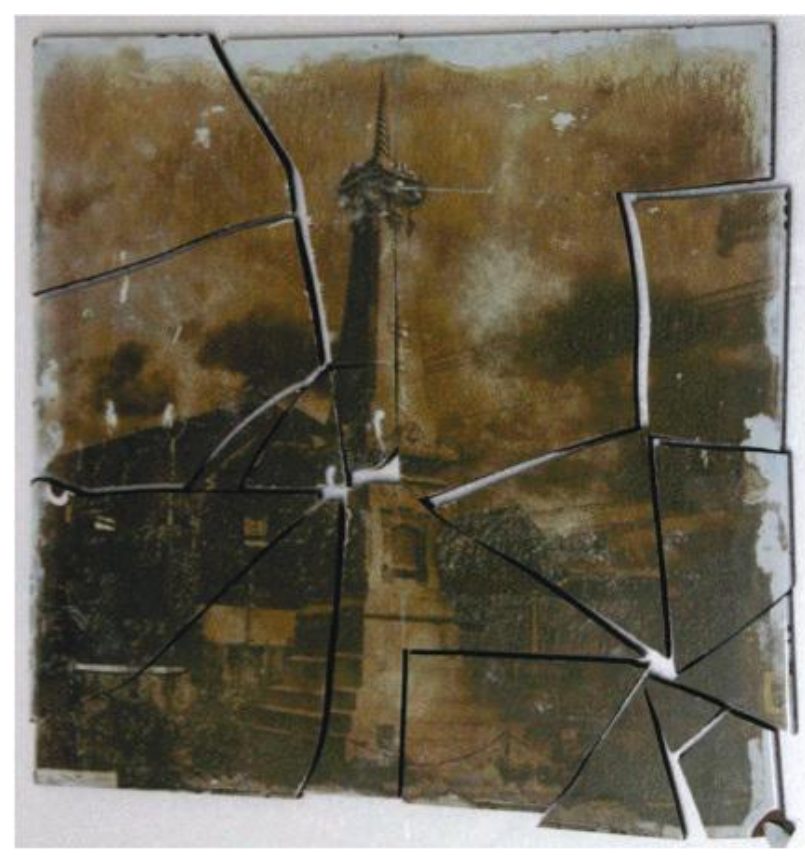

Gambar. 9

Alan Ridho Irelzanov “Ada Apa Dengan Jogja (AADJ)"

Vandyke pada Kaca dan Keramik 30 x $30 \mathrm{~cm}$ (Sumber: Katalog Pameran IMAJI\#2: Alternative Photographic Processes, Neo Journalism Club, Galeri Foto Jurnalistik Antara, FSMR ISI Yogyakarta, Jakarta dan Yogyakarta, 2016, halaman 12)

Gambar 9 adalah karya Alan Ridho Irelzanov, salah satu anggota aktif KOPPI. Foto tersebut menampilkan Tugu "Pal Putih" yang merupakan ikon kota Yogyakarta yang dibangun pada masa pemerintahan Hamengku Buwono I (1755). Tugu ini merupakan tonggak pendirian kerajaan Yogyakarta. Alan menggunakan teknik cetak Vandyke brown yang diaplikasikan di atas keramik. Keramik yang telah dicetak kemudian dipecah dan disusun kembali. Susunan keramik pecah itu akhirnya menghasilkan garis-garis tidak beraturan yang mengenai subject matter karya ini, yaitu tugu "Pal Putih". Karya ini telah dipamerkan di Galeri Foto Jurnalistik ANTARA Jakarta pada tanggal 3-16 Juni 2016. Menurut Alan, karya ini dibuat sebagai bentuk keprihatinan dirinya atas berbagai pemasalahan sosial budaya yang belakangan ini terjadi di Yogyakarta. Dalam konsep karyanya Alan menyatakan "Maraknya pembangunan hotelhotel dan mall (pusat perbelanjaan) beberapa tahun terakhir telah merusak tata ruang kota dan keistimewaan Daerah Istimewa Yogyakarta. Tidak berbeda dengan kondisi di kota besar seperti Jakarta. Jadi, apa yang istimewa dari Yogyakarta sekarang, apakah masih nyaman dan seistimewa dulu?" Tampilnya tugu "Pal Putih" di tengah gambar tentu dimaksudkan agar tugu "Pal Putih" menjadi pusat perhatian dalam karya ini. Namun kehadiran garis tidak beraturan sebagai dampak dari pemecahan keramik member tekanan yang berbeda. Kesan perpecahan, ketidak-bersatuan sangat terasa dalam karya ini. Nuansa cokelat khas cetakan lama semakin mendramatisasi impresi yang tercipta. Tindakan memecahkan keramik bergambar Tugu "Pal Putih" yang dilakukan Alan seolah mengatakan kepada pemirsa bahwa Yogyakarta kini adalah Yogyakarta yang tidak lagi Istimewa. Yogyakarta kini bukan lagi kota budaya, namun telah menjadi kota metropolitan.

Dalam karya lain, Galih Caesar Prabowo (Gambar 10) menciptakan karya berjudul "Membeli Jabatan", dicetak dengan teknik Vandyke brown di atas kertas. Foto karya Galih menampilkan seuntai dasi di tengah hamparan uang dalam posisi acak. Galih dalam karya ini menyampaikan pesan moral kepada para pejabat yang menghalalkan berbagai cara untuk mendapatkan kedudukan. Sebagaimana ia sampaikan dalam konsep karyanya "Setiap manusia pasti ingin mendapatkan kedudukan, manusia selalu ingin diakui, maka manusia ingin mendapatkan jabatan tetapi beberapa manusia ingin mendapatkan posisi atau kedudukan yang lebih tinggi dengan cara instan maka mereka menghalalkan segala cara untuk mendapatkan jabatan yang lebih tinggi." 


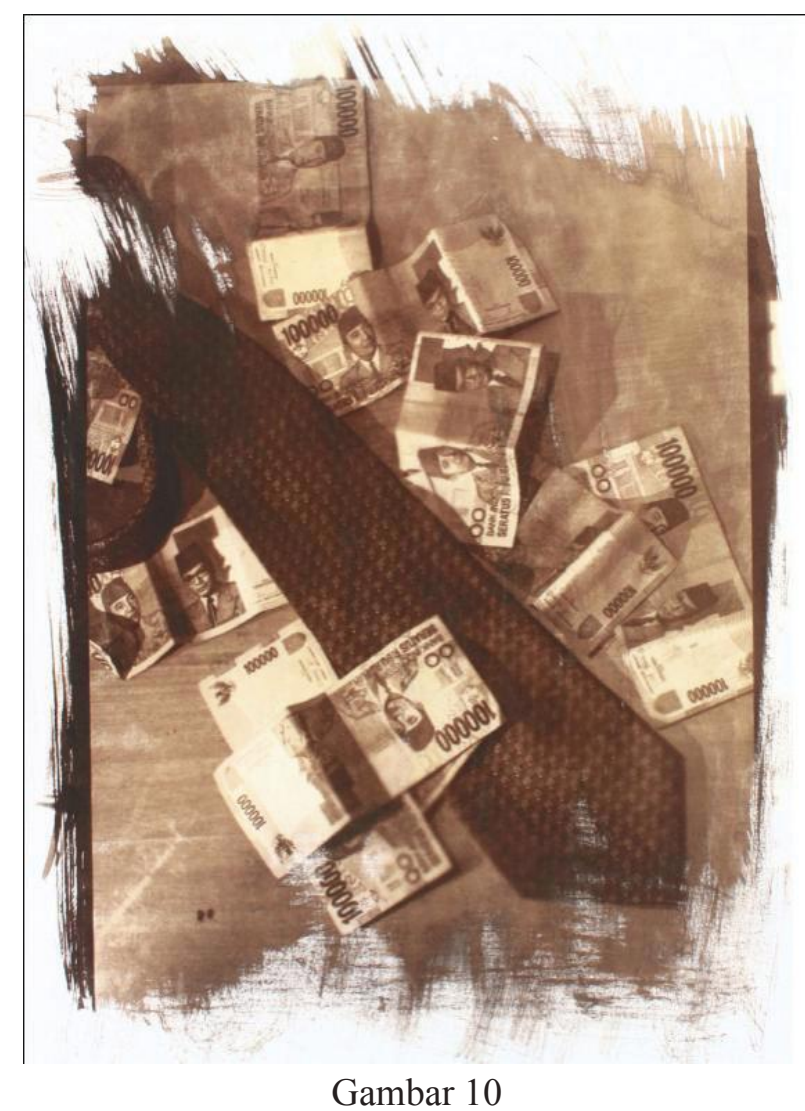

Galih Caesar Prabowo, "Membeli Jabatan" Vandyke di atas kertas, $50 \times 33 \mathrm{~cm}$.

(Sumber: Katalog Pameran IMAJI\#2: Alternative Photographic Processes, Neo Journalism Club, Galeri Foto Jurnalistik Antara, FSMR ISI Yogyakarta, Jakarta dan Yogyakarta, 2016, halaman 19)

Berdasarkan karya dan konsep yang ditawarkan oleh Galih, pesan karya ini dapat ditangkap dengan baik. Galih memanfaatkan objek-objek yang secara konotatif memang menggiring interpretasi pemirsa untuk mengaitkan antara uang dan kekuasaan. Terlebih permasalahan korupsi di segala lini sedang marak di Indonesia.

Berikutnya, karya Danysswara (Gambar 11) dihadirkan dengan cara memasang enam piring yang di atasnya dicetak dengan teknik cyanotype. Enam piring itu masing-masing menampilkan pose-pose selfie yang diperagakan oleh para remaja. Dalam konsep karyanya, Danysswara mengibaratkan perilaku selfie sudah seperti kebutuhan makan dan minum.
Itulah alasan mengapa Danysswara memilih piring sebagai media cetak untuk karyanya. Piring dijadikan media penyambung pesan sinis tentang perilaku selfie di masyarakat.

Dalam karya foto analog hitam putih, karya Syakifa Fitri (Gambar 12) dapat dijadikan contoh untuk dibahas. Syakifa, melalui karyanya yang berjudul "Building", memamerkan karya fotogram di atas kertas foto hitam putih. Ia melakukan eksplorasi bentuk-bentuk dua dimensional melalui proses cetak foto analog. Karya itu memperlihatkan bentuk profil manusia secara siluet karena dalam bidang siluet itu terdapat susunan bentuk yang disusun sedemikian rupa sehingga hampir memenuhi budang hitam siluet manusia yang ditampilkan. Bentuk-bentuk itu dihasilkan dari peletakan benda-benda solid di tas kertas foto yang disinari dan kemudian diproses di kamar gelap. Karya ini dapat tercipta berkat upaya eksplorasi dan eksperimentasi media dan ide yang ingin ditampilkan. Bagi Syakifa, eksperimen ini hanya mungkin dilakukan di dalam proses fotografi analog.

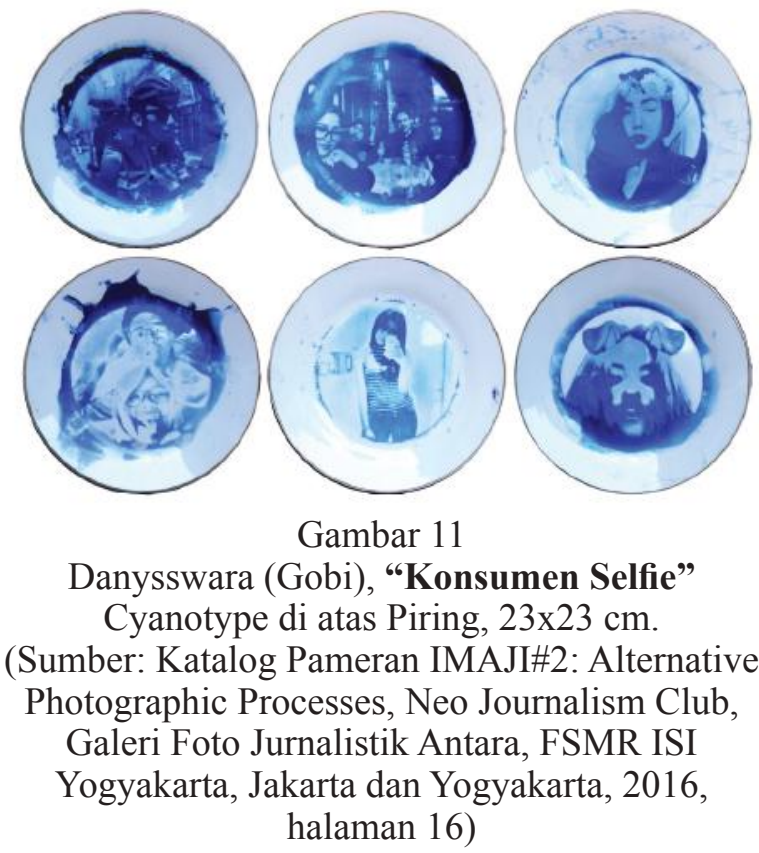




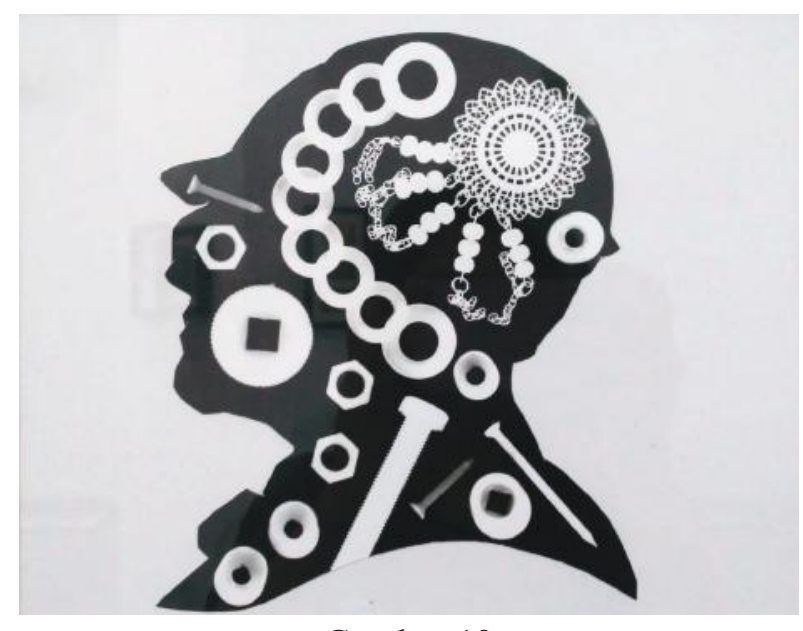

Gambar 12

Syakifa Fitri, "Building"

Fotogram di atas kertas foto hitam putih, 20x20 $\mathrm{cm}$.

(Sumber: Koleksi pribadi)

Berdasarkan ulasan pada empat karya yang dihasilkan oleh anggota KOPPI, terdapat sejumlah hal yang dapat dibahas. Sebagaimana telah dikemukakan di bagian awal, akan dibahas bagaimana para anggota KOPPI bernegosiasi dengan karakter, teknik, media, dan tema karya dalam melakukan praktik foto analog dan foto cetak tua. Pembahasan karya-karya anggota KOPPI akan meminjam ide expressive form yang dikemukakan (Langer, 1953) sebagai berikut,

A work of art, on the other hand, is more than an "arrangement" of given thingseven qualitative things. Something emerges from the arrangement of tones or colors, which was not there before, and this, rather than the arranged material, is the symbol of sentience. The making of this expressive form is the creative process that enlists a man's utmost technical skill in the service of his utmost conceptual power, imagination. Not the invention of new original turns, nor the adoption of novel themes, merits the word "creative," but the making of any work symbolic of

\section{feeling, even in the most canonical context and manner.}

Berdasarkan karya-karya yang telah diulas dalam tulisan ini, apa yang dilakukan oleh anggota KOPPI dalam berkarya merupakan bentuk kesadaran untuk menyampaikan sesuatu. Mereka mengaransemen aspek-aspek formal yang terdapat pada media yang mereka gunakan menjadi kumpulan bentuk yang bermakna. Cetakan foto dengan cara lama, sebagaimana terlihat pada gambar, secara visual memiliki ciri yang khusus (kesan antik, kusam, dan tidak beraturan) dimanfaatkan sedemikian rupa untuk menyampaikan tema atau isu yang sesuai. Di samping itu, terbukanya kemungkinan bahwa pencetakan foto dapat dilakukan di atas media selain kertas juga dimanfaatkan sedemikian rupa untuk menyampaikan pesan. Dalam kasus karya Alan (Gambar 9) misalnya, pilihan Alan memecahkan keramik yang telah dicetak merupakan upaya untuk menyampaikan pesan dan imajinasinya tentang pecahnya keIstimewaan Yogyakarta. Expressive form yang ditunjukkan dalam karya Alan, Danysswara, dan Syakifa merupakan contoh bagaimana aspek teknis, material, karakter, dan tema berhasil menemukan titik temu dalam wujud karya yang "bersuara", terdapat muatan pesan di dalamnya. Selain itu, karya yang dihadirkan oleh tiga orang tersebut memiliki keunikan yang tidak mudah dibuat secara digital.

Sementara itu, karya Galih (Gambar 10) walaupun memiliki tema yang kuat, namun masih belum menunjukkan titik temu aspek teknis, material, karakter, dan tema. Hal ini terjadi karena apa yang dilakukan oleh Galih masih dapat dicapai dengan bantuan hardware dan software fotografi digital sebab masih dicetak di atas bidang yang rata. 
Penting untuk mengetahui alasan yang mendasari anggota KOPPI untuk menciptakan karya-karya yang menunjukkan interaksi antara teknik, bahan, karakter, dan tema. Bagi Danysswara, "praktik fotografi dengan digital sudah terlalu umum dilakukan. Kami ingin sesuatu yang berbeda. Awalnya kami memandang old print ini sebagai sarana belajar tentang masa lalu, namun saat ini saya membutuhkan alasan yang kuat untuk tetap bertahan melaukan praktik ini. Kalau hanya sekadar bisa mencetak, membosankan juga, karena saya sudah bisa" (Wawancara, 25 Juni 2017). Pernyataan Danysswara ini merupakan salah satu contoh bagaimana sesungguhnya sebuah ketertarikan harus diimbangi dengan pengembangan kemungkinan yang lebih jauh. Dalam hal ini, old print akan mereka tinggalkan bila bagi mereka sudah tidak dapat dikembangkan lagi sabagai sarana penyampaian pesan. Hal senada juga dinyatakan oleh Alan, "kita perlu pikirkan bagaimana old print itu bisa diperkuat dengan konsep karya yang kuat, karena bila hanya sekadar mencetak, lama-lama akan bosan" (Wawancara, 21 Juni 2017).

Dalam wacana old photographic processes didunia, tidakbanyakterlihatupayapemanfaatan karakteristik hasil praktik ini sebagai bentuk expressive form. Berdasarkan hasil pengamatan di berbagai laman old photographic processes (www.alternativephotography.com), terlihat bahwa praktik ini di Eropa, Amerika, dan belahan dunia lain lebih cenderung mengarah pada proses reaktualisasi teknis cetak. Dalam kata lain, praktik old photographic processes dilakukan atas dasar keinginan untuk mencoba kembali dan keinginan untuk mendapatkan hasil cetakan yang akurat sebagaimana karakter asli cetakan yang dicoba. Di samping itu, praktikpraktik old photographic processes di banyak tempat lebih mementingkan sisi keindahan, dan kurang memerhatikan isi pesan yang ingin disampaikan.

Apa yang dilakukan oleh anggota KOPPI dipandang sebagai sesuatu yang penting karena negosiasi aspek teknis, material, karakter, dan tema dalam fotografi analog dan old photographic process tidaklah mudah. Mereka harus memikirkan segala sesuatunya dari titik nol. Sebagai bagian dari sejarah perkembangan fotografi, old photographic processes dan fotografi analog tentu memiliki sejumlah "kekurangan". Untuk memulai memasuki dua praktik tersebut, banyak hal yang harus mereka hadapi. Hal pertama tentu mereka harus menyelesaikan perkara pengetahuan tentang fotografi masa lalu; mereka juga harus mencari bahan-bahan yang semakin sulit didapat; dan yang paling berat ialah mereka harus dapat mengatasi kelemahan teknis dari dua praktik fotografi tersebut. Pada old photographic process, masalah kesesuaian bahan kimia dan media cetak yang digunakan menjadi permasalahan tersendiri. Tidak semua bahan cetak akan menunjukkan respons yang menggembirakan saat diaplikasikan bahan-bahan kimia fotografi. Mereka juga masih menghadapi permasalahan keawetan/ kepermanenan cetakan yang rentan terhadap kondisi cahaya dan perubahan kelembaban, terlebih KOPPI berada di daerah tropis.

\section{SIMPULAN}

Expressive form menjadi titik temu dalam negosiasi teknik, media, dan tema karya yang dilakukan oleh KOPPI. Pemahaman tentang karakter media yang digunakan untuk mencetak serta pendayagunaan bahasa visual sangat diperlukan untuk eksplorasi lebih jauh tentang tema karya yang diangkat. Appearance 
old photographic processes bagi anggota KOPPI adalah sebentuk bahasa visual yang khas. Kebermaknaan praktik old photographic processes dan fotografi analog bagi anggota KOPPI tertelak pada seberapa jauh praktik ini dapat menyuarakan isu-isu yang lebih dari sekadar keindahan bernuansa masa lalu. Proses pengkaryaan selalu dimulai dengan mempertentangkan praktik ini dengan praktik fotografi digital. Mempertanyakan alasan yang kuat sehingga penciptaan melalui praktik ini dapat dianggap penting. Dalam kata lain, proses reaktualisasi dalam praktik ini dianggap berhasil bila karya yang dihasilkan tidak dapat dicapai dengan teknologi cetak digital.

\section{KEPUSTAKAAN}

Bas, J. (1971). Pembuatan Emulsi pada Kain, Piring, Katja, Porselen, Gelas, dll, Pembuatan Gambar Tempel untuk Praktek. Bandung: Cahaya Remadja.

Brooke-Ball, P. (1997). Kisah Sukses Bisnis George Eastman dan Kodak. Jakarta: PT. Gramedia Pustaka Utama.

Coe, B., \& Haworth, M. (1983). A Guide To Early Photographic Process. London: Victoria \& Albert Museum with Hurtwood Press.

Farber, R. (1998). Historic Photographic Processes. London: Allworth Press.

"Katalog Pameran IMAJI\#2: Alternative Photographic Processes, Neo Journalism Club.” (2016). Jakarta \& Yogyakarta.

"Katalog Pameran The Power of Art, Dies Natalis 25 tahun Program Studi Pengkajian Seni Pertunjukan dan Seni Rupa.” (2016). Yogyakarta.

Langer, S. K. (1953). Feeling and form. New York: Scribner.

Suess, B. J. (2003). Creative Black and White Photography: Advance Camera and Darkroom Techniques. New York: Allworth Press.

\section{Nara Sumber}

Alan Ridho Irelzanov, Anggota KOPPI, ISI Yogyakarta.

Danysswara, Alan Ridho Irelzanov, Anggota KOPPI, ISI Yogyakarta.

Syakifa Fitri, Alan Ridho Irelzanov, Anggota KOPPI, ISI Yogyakarta. 